\title{
For the Family: One Teen's Self-Selected Digital Literacy Practices
}

\author{
Maria Del Rosario BARILLAS \\ Pacific Oaks College \\ and \\ Laurie MacGILLIVRAY \\ University of Memphis
}

A teenager, technology, and his family

One Sunday in November, I drop by to spend time with Gustavo and his family. As I enter the den where Gustavo works on the computer, I see CD cases and covers strewn all over the desk, as well as a list of songs with the names of the artists. Gustavo has just finished downloading music and text for his cousin, Irene. He is in the process of creating a CD cover for which he was cutting and pasting a mosaic of the different rock bands featured on the CD, including the titles of songs and artists. He asks me if I want to hear one of his favorite songs, "The Scientist." As the song plays, his younger brother and sister walk in, drawn by the music (Obs. Notes 11/03).

This is an example of a typical Sunday afternoon in the Pedraza household. Sixteen-year old Gustavo (pseudonym) amuses himself using technology to provide entertainment for family members. Gustavo came to the United States from Mexico when he was nine years old with his family. The eldest of three children, Gustavo is responsible for a wide range of reading and writing tasks many of them requiring the use of technology.

As technology becomes a basic necessity in the lives of American families, populations who in the past have not had access to technology, will begin to engage with it as part of their daily functions. Consequently, the way that these families, and especially the children take hold of digital literacies, will depend on their cultural ways of knowing and their economic needs (Browning- Aiken, 2004; De La Peña \& Orellana, 2007). In contrast to studies that document the limited access to technology in minority populations because of economic pressures (Kaiser Family Foundation, 2004; Kupperman \& Fishman, 2002), this paper focuses on one Mexicano teen's active participation with technology outside of school. It shows how economic need in the family served as the driving force for the purchase and use of the computer.

Two questions framed our work: What are one teen's self-selected digital literacy practices? How do these literacy practices contribute to the family?

\section{Theoretical Framework}

This study draws on the notion of social literacy practices, which refers to the "general cultural ways of utilizing literacy which people draw upon in particular situations" (Barton, 2001, p. 96). Within a literacy practice, there are specific literacy events which are the visible episodes of individuals' experiences mediated through text (Street, 2001). An illustrative example of this notion is the making of a card for someone else, such as a Mothers' Day card. This is an 
observable act, a literacy event. Yet the act becomes meaningful when it is situated within the broader outcome of connecting with others by creating a personal message (literacy practice). (For other examples see Barton \& Hamilton, 2000, MacGillivray \& Curwen, 2007). Exploring situated meaning is critical when examining digital literacies due to the constant evolution of related social practices (Leu, Kinzer, Coiro, \& Cammack, 2004).

\section{Related Literature}

\section{Literacies in the home and Latino families}

Foundational research with Mexican American immigrants (Farr \& Guerra, 1995; González, 2001; Gonzalez et al, 2004; Guerra, 1998; Moll, Amanti, Neff, \& Gonzalez, 1992; Vásquez, Pease-Alvarez, \& Shannon, 1994) identified funds of knowledge, literacy in and out of school, and language in Mexicano communities. These studies offer insight into the way parents pass on skills and traditions to their children by modeling and engaging the children in target activities, such as cooking and communicating with distant relatives. This work highlights the importance of the home language in Latino familial interactions.

Latino households have been found to use technology less than other racial groups (U.S. Department of Commerce, 2000) but the numbers are increasing. The percentage of Hispanic households who use technology rose from $12.6 \%$ to $23.6 \%$ over a 20 month time period (U.S. Department of Commerce, 2000). As part of the general population, Latino households are shifting from dial-up connections to broadband Internet. This shift was found to lead to an increase in use and more diversity in the ways families interact with computers (U.S. Department of Commerce, 2004).

\section{Social literacies and technology beyond the school}

Technology has impacted the way we think about teens, their social networks, and their literacy practices (i.e., Alvermann, et al, 2001; Chandler-Olcott \& Mahar, 2003). Research has documented the way media exploration can allow teens to display literacy abilities not shown in school (Alvermann, et al., 2001) and support social interaction (Chandler-Olcott \& Mahar, 2003). The youths in these studies engaged in social literacy practices, which were not only enjoyable but which also helped to develop their literacy skills.

In contrast to the studies on digital activities situated in after school activities, De La Peña and Orellana (2007) surveyed and interviewed teens to examine their use of technology across settings. By examining Latino teens, they offered a window into the technology as a socially embedded activity. They found teens to have varied technological practices and to play a role in the running of the household. Our study extends this work by offering a close examination of one Latino teen as a "competent social actor" (De La Peña \& Orellana, 2007) who strategically uses literacy to interact with technology for personal and familial pleasure and as a tool for economic success. 
Method

\section{Participants}

Our case study features Gustavo Pedraza, who came to the United States eight years ago from Puebla, Mexico, with his parents, an aunt, and two younger siblings. A 16 year-old junior in high school, Gustavo is bilingual and biliterate. He is the fulcrum of the family, the oldest male child, and the most advanced bilingual and biliterate member of the family. Every day he attended school, then went to his family's business until 6:00 p.m., at which time he returned home with his parents. They ate dinner together, and then he did his homework and spent time on the Internet. He was an 'A' student at school. On the weekend, Gustavo went to the family-owned business and worked a few hours each day. At home Gustavo used broadband access to the internet to work on homework assignments, downloaded music and provided entertainment for his siblings by watching movies from his computer library of films. The children also played computer or video games. With his parents working long hours, Gustavo and his two siblings spent most of their free time inside. Occasionally, the family went to the park for a picnic and play day.

Gustavo had no friends he saw outside of school or interacted with through instant messaging, phone calls, or email. His family prioritized schoolwork and his help at the business, so any form of interactions outside the family were discouraged. For example, Gustavo shared an email he received from Hilary Duff (teen actress and singer) inviting her fan club members to a private concert. His parents did not seriously consider this as an option deciding it was more important that Gustavo assist his parents in the family business. For them, working and staying close to the family was more of a priority than the teen's social life with peers.

\section{Data Collection \& Analysis}

The data for this study was collected for 10 months with thirteen home visits to conduct interviews, and observations of Gustavo. Observations in the home included watching the teen working on the computer individually and with others, informal discussions, and interacting with the family over meals. During the final three months of the study, María, the first author also taught English classes to Gustavo's parents at the request of the mother. She also visited the family-owned bakery/candy factory business four times. Texts such as song lyrics downloaded from the Internet, CD covers, lists of songs, business cards, price lists and mock business cards were collected and analyzed.

There were many informal discussions during the fieldwork as well as formal semi-structured interviews with Gustavo and his father, and one with his mother. Topics included Gustavo's literacy and technology practices, his daily routines, responsibilities, and conceptions of culture, bilingualism and biliteracy.

Analysis was based on the theoretical framework of literacy practices. Digital literacy events as described in field notes and interviews were identified, clustered into domains and institutions and linked to larger cultural practices. We then coded accordingly, within the family institution across the domains of home and work (the family business). Next, the events were linked to 
larger cultural practices. The goal was to make the connections between digital literacies and larger cultural practices. For example, Gustavo sometimes searched for websites related to the family business and signed his father up as a member of bakery product organizations in order to "get free stuff" (a literacy event). This is one set of actions that when viewed with others can be understood as part of the broader social practice of supporting the family business and thus contributing to the health of the family.

\section{Findings}

By examining specific literacy events in which Gustavo participated, we gain insight into the way they are linked to larger literacy practices that served the family. His digital literacy activities served the family in four ways by: a) contributing to his family's fiscal resources, b) brokering popular culture for his siblings, c) scaffolding content through the primary language, and d) bridging generations and cultural knowledge. For the sake of clarity, we discuss the findings in categories, although there is a fluidity across these demarcations.

\section{Providing fiscal resources}

As an employee of his family business, Gustavo contributed to the fiscal stability of the company. He played a key role in running the family owned bakery/candy factory, working after school and on weekends, using his digital literacies to promote the family business. Even though his parents referred to Gustavo as "un trabajador" (as an employee), Gustavo was an active member of the company. He drew upon his expertise in technology and literacy, his business savvy, and his developing understanding of the Mexican candy-making tradition in order to, locate websites where he ordered "free stuff," for the family, such as bakery catalogues, generate computer candy labels, price and inventory lists, business cards and other documents his father requested. Gustavo's parents decided on the final format on many of the documents that he created.

Those specific literacy events link to the larger social value of serving family. Notably, these literacy events also offered reciprocity between the family members. He learned the candymaking tradition from his native Puebla as he carried out tasks for the business. Because

he was often physically at the business working on the Internet he was able to learn from his parents. Together, these technological literacy events reflect the larger cultural practice of family members working together, in this case for fiscal stability.

\section{Brokering popular culture}

Through digital literacy activities, Gustavo acted as an intermediary in passing on both tacit and explicit information about popular culture in both English and Spanish. Gustavo often entertained his siblings by playing on the computer using pop culture icons as well as his library of family photos. He created a mock business card for himself in which he placed a photograph of his face on the body of the actor, Pierce Brosnan as Agent 007, dressed in a tuxedo and holding a gun. He included a comical caption, which read, "Gustavo Pedraza, Agent 008, Expert in infiltration and investigation." He made similar mock business cards for his brother and sister, 
allowing them to choose from a variety of American popular culture icons. For example, he included the face of his sister on the body of Marilyn Monroe in the famous scene of her in a white dress standing over a subway vent. As he played with graphics, chose whom he wanted to emulate, and negotiated both images and words, he further facilitated literacy when he provided the younger children with documents (mock business cards) to share with their friends. In this literacy event, Gustavo passed on to his siblings an aspect of American popular culture with which they were not yet familiar. Although he had limited interactions with the peer culture, he was an ardent admirer of Hillary Duff. This was one of the few Internet activities in which he did not involve his siblings illustrating his consideration of content.

\section{Bilingualism and biliteracy}

The brokering of popular culture often integrated a variety of complex literacies in more than one language within a social context of familiar warmth. In the midst of interacting around popular culture, Gustavo and his siblings made use of their bilingual skills in Spanish and English. For example, during one observation he modeled the fluidity of language, both oral and written. He led the younger children to a Spanish language website, Lopeor.com (TheWorst.com). This interactive website geared for a teen audience, provided entertainment such as jokes, horoscopes, chat rooms, finding romance, noticias weird (weird news), and an educational bulletin with information on a variety of topics from literature to science, social studies and more.

Gustavo used Spanish to navigate the web site and facilitated understanding for family members. Participation in jokes and games in Lopeor.com required the reading of a warning in sophisticated Spanish as in the following excerpt, "A continuación es un retrato fantasmagórico, debes tener el audio configurado, sube el volumen hasta que escuches bien el test de sonido que está sonando" (The following is a phantasmagoric picture; you should configure the audio, have the volume high enough to hear the sound test that is playing). During this interaction, it was essential that the children not only decode the text but also discern the content of the message before continuing with the game. As the children read, followed directions, and talked with one another, Gustavo mediated understanding for the younger children.

Gustavo also mixed English and Spanish when communicating orally with his siblings and cousins. For instance, in a single sentence Gustavo said, "Look at it closer hasta que aparezca el ghost [until the ghost appears]." Another time, Gustavo drew on his bilingualism as he gave his cousin instructions about a visual joke on the computer, "You're not supposed to laugh for 30 seconds. No te puedes reir por 30 segundos. Si te empiezas a reír estás loco y si no te ríes eres normal." (You can't laugh for 30 seconds. If you start to laugh you're crazy, if you don't you're normal).

In this literacy event, Gustavo, his siblings and their cousins used two languages to communicate with each other and to make sense of games and jokes through technology. The way that Gustavo shifted languages, depending on the situation, shows not just the social nature of literacy and language, but also how he provided access for his young family members to sophisticated text in Spanish. His technology and literacy skills allowed him to pass on to his family members 
aspects of both American and Latino popular culture that they might not be able to attain on their own.

Gustavo additionally made use of his two languages through music. His father enjoyed diverse musical genres such as, Mexican corridos, popular Spanish language music, classical, and American pop music of the 60's and 70's; these have also influenced Gustavo's musical preferences. Gustavo's music collection overlapped with his father's and included songs from the 60's through the present in English, Spanish, French, and German. These events represent the ways digital literacies link to the cultural practice of bridging generations.

\section{Bridging generations}

One evening while María was visiting the house, Gustavo asked all of his family to gather around the computer. The sounds of an alterative rock song, "The Scientist" by System of a Down, blared out of the computer speakers as photographs of family events taken during a span of seven years faded in and out on the screen. Using his digital literacies, Gustavo had created a multimedia presentation with family photographs taken since their arrival to the U.S. Gustavo's younger brother, who was acquiring his older brother's taste in music, selected the song. And like their youngest son, the adult Pedrazas were becoming familiar with mainstream rock music that in this event was juxtaposed to their immigrant experience. The images of this Mexicano family in the United States (breaking piñatas, playing in the park with other family members, and gathered around a birthday cake), presented on the computer along side with a rock song from American pop culture chosen by the younger son, exemplifies the reciprocal transformation of two cultures. This instance represents Gustavo's rewriting of the family history documenting their experiences in their adopted country. They physically huddled around the computer as they viewed their history from a different perspective.

Gustavo's bilingual and bicultural understandings served the entire family. In another instance, Gustavo and his father shared an interest in the music of Cat Stevens, a popular artist from the 70's. When Gustavo's father was an adolescent, the age of his son, he worked for his father driving public buses in the Mexican city of Durango. It was during this period that Gustavo's father spent countless hours listening to the radio, and especially to American popular music. Gustavo explained, "When he [my dad] was in Mexico, he didn't know the meaning of the songs. Now he does because I translate them for him." In this case as in others, Gustavo provided understanding of the songs for his father. This literacy event links to the cultural practices which serve family by bridging generations.

Gustavo's familial relationships were situated around his use of the computer. He created niches for his siblings to understand Internet sites and rewrote the family history through images and sound, thereby bridging generations, cultures, and languages to connect with his father. Gustavo's position as mediator provided him with opportunities to demonstrate his talents, contribute to his family in multiple ways, and receive affirmation and respect from all members of his family. With his computer, Gustavo brought the family together. 


\section{Discussion}

By examining the relationship between an immigrant teen's computer practices and his familial interactions, this deepens research on the self-initiated digital literacy practices of Mexicano teens as situated within the demands common to immigrant families (De La Peña \& Orellana, 2007). In addition, previous studies show that economics is an issue for Latino youths' lack of access to technology (Kaiser Family Foundation, 2004; U.S. Dept. of Commerce, 2004). Yet, for Gustavo's family, during financial hardship, the parents continued to update their technology. Gustavo's literacy practices served his family and were shaped by his position as a teenager in an immigrant family.

Aspects of Gustavo's life might reflect that of other teens: pressure to achieve in school interaction with peers face-to-face, through live chats, and text messaging, yet, he did not spend time outside of the home communicating with friends. For this immigrant teen-ager, as the oldest, fully biliterate and bilingual child, his duties to help his family in the business and to be a role model for his younger siblings superseded his engagement in social, peer relationships. His developing digital skills were turned inward to his family with most of his interactions with teens occurring at school through classmates. He engaged in teen culture through his involvement with the Hillary Duff Fan Club and was interwoven with numerous sites he explored with his siblings.

In contrast with many immigrant families (Browning-Aiken, 2005), Gustavo's family had few extended relatives, which led to a rather insular life as he engaged socially with two younger cousins, his siblings, and a few older relatives. A strong desire to achieve economic success also framed the way the family spent their time and Gustavo's parents relied on him for both personal and business dealings. The family supported digital literacy events, which integrated language (De la Peña \& Orellana, 2007; Kupperman \& Fishman, 2000), business, musical genres and pop culture as long as it occurred in the house. But, Gustavo also worked to meet his parents' expectations of becoming "American" while maintaining his Mexican identity. Ties to the home culture were nurtured and honored.

\section{Implications}

Implications address technology, culture and familial interactions. First, technology is a space where family members can come together across cultures and languages. Digital literacy practices can be used for business, but also can be more broadly used as a tool to ease intergenerational tensions, such as those often experienced by immigrant families. As these newcomers adjust to the hybridity of American culture, older children can provide a bridge to new possibilities and open doors to understanding the "American" way of life through technology.

Second, older siblings can serve as filters to content. Older brothers and sisters can be responsible and more sensible guides to Internet websites. As part of the traditional expectations of the oldest child, Mexicano youth are often given the role of substitute parents and are expected to serve as mentors for the younger children. Hence, older children are not just empowered but also entrusted to safely usher younger siblings through the world of technology. 
Third, understanding the way Mexicano teens use technology in the home can help educators and researchers consider cultural dynamics specific to this community, often overlooked in Mexicano families (De La Peña \& Orellana, 2007). It is clear from this study that technology like other literacies is appropriated by family members and used in practical and meaningful ways. As these families are situated in culturally specific contexts, technology use also reflects a crossing into the mainstream culture in which they rely for survival.

Lastly, the funds of knowledge that immigrants bring from their homelands play a key role in the educational, social, and economic achievement of the families (Gonzalez, et. al, 2004; SandovalTaylor, 2005). Survival and a desire to excel in their new land can frequently dictate the choices they make to ensure success. Consequently, purchasing computers and Internet subscriptions for their children is an investment. What young people contribute through their digital literacy events along with their parents' funds of knowledge can provide life-long benefits and richer lives.

\section{References}

Alvermann, D.E., Hagood, M.C., Williams, K.B. (2001). Image, language, sound: Making meaning with popular culture. Reading online. www.readingonline.org

Barton, D. (2001). Directions for literacy research: Analysing language and social practices in textually mediated world. Language and Education, 15, 92-104.

Barton, D.\& Hamilton, M. (2000). Literacy practices. In D. Barton, M.Hamilton, \& R. Ivanic, (Eds.) Situated literacies: Reading and writing in context (pp. 7-15). London: Routledge.

Browning-Aiken, A. (2005). Border Crossings: Funds of knowledge: Within an immigrant household. In C. Gonzalez, L.C. Moll, \& C. Amanti, (Eds.), Funds of knowledge: Theorizing practices in households, communities, and classrooms (pp. 167-182). New Jersey: Lawrence Erlbaum.

Chandler-Olcott, K. \& Mahar, D. (2003). “Tech-savviness” meets multiliteracies: Exploring adolescent girls' technology-mediated literacy experiences. Reading Research Quarterly, 38, 356-385.

De la Peña, Y. \& Orellana, M.F. (2007). An examination of Latino immigrant youths' out of school literacies. Psicologia Escolar e Educacional, 11, 71-82.

Farr, M., \& Guerra, J. C. (1995). Literacy in the community: a study of Mexicano families in Chicago. Discourse Processes, 19 (1), 7-19.

González, N. (2001). I am my language: Discourses of women and children in the borderlands. Tucson, AZ: University of Arizona Press. 
Gonzalez, N., Moll, L.C., Amanti, C. (2004). Funds of knowledge: Theorizing practices in households, communities, and classrooms (pp. 154-166). New Jersey: Lawrence Erlbaum.

Guerra, J. C. (1998). Close to home: Oral and literate practices in a transnational Mexicano community. New York, NY: Teachers' College Press.

Kaiser Family Foundation. (2004). Children, the digital divide, and federal policy (Issue Brief). Menlo Park CA.

Kupperman, J. \& Fishman, B. (2000). Academic, social, and personal uses of the Internet: Cases of students from urban Latino classrooms. Journal of Research on Technology in Education, v. $34,(2), 189-215$.

Leu, D. J., Jr., Kinzer, C.K., Coiro, J., \& Cammack, D.W. (2004). Toward a theory of new literacies emerging from the Internet and other information and communication technologies. In R.B. Ruddell, \& N. Unrau (Eds.), Theoretical models and processes of reading (5th ed., pp. 1570-1613). Newark, DE: International Reading Association. Available: http://www.readingonline.org/newliteracies/lit_index.asp?HREF=leu/

MacGillivray, L., \& Curwen, M. (2007). Tagging as a social literacy practice. Journal of Adolescent and Adult Literacy, 50(5), 354-369.

Moll, L.C., Amanti, C., Neff, D. \& Gonzalez, N. (1992). Funds of knowledge for teaching: using a qualitative approach to connect homes and classrooms. Theory Into Practice, 31, (2), 132-141.

Sandoval-Taylor, P. (2004). Home is where the heart is: A funds of knowledge-based curriculum module. In C. Gonzalez, L.C. Moll, \& C. Amanti, (Eds.), Funds of knowledge: Theorizing practices in households, communities, and classrooms (pp. 154-166). New Jersey: Lawrence Erlbaum.

Street, B. (2001). Literacy events and literacy practices. In K. Jones (Ed.), Multilingual Literacies: Reading and Writing in Different Worlds. Philadelphia, PA: John Benjamin Publishing Company.

U.S. Department of Commerce. (2000). A report on Americans' access to technology tools. Washington, D.C.: U.S. Department of Commerce. Retrieved January 25, 2008 from http://search.ntia.doc.gov/pdf/fttn00.pdf .

U.S. Department of Commerce, National Telecommunications and Information Administration. (2004). A nation online: How Americans are expanding their use of the Internet. Washington, DC: U.S. Department of Commerce. Retrieved February 13, 2008 from http://www.ntia.doc.gov/reports/anol/index.html.

Vasquez, O.A., Pease-Alvarez, L., Shannon, S.M. (1994). Pushing boundaries: Language and culture in a Mexicano community. Cambridge University Press 


\title{
Author Biographies- Del Rosario Barillas and MacGillivray
}

María Del Rosario Barillas is a core-faculty member of Pacific Oaks College in Pasadena, California in the Teacher Education Program. She has been an elementary and middle school teacher for 26 years. She received her Ph.D. in education from the University of Southern California in 2004. María is interested in researching the out of school literacy practices of middle and high school Latino students.

Laurie MacGillivray is an Associate Professor in the College of Education at the University of Memphis. She taught elementary school in Texas. Her research interests include literacy practices in and out of schools by individuals and families with particular attention to homeless children. She has published widely in journals such as Curriculum Inquiry, Journal of Adolescent and Adult Literacy, Journal of Latinos in Education, and The Reading Teacher.

\begin{abstract}
This case study focuses on one adolescent immigrant's experience serving as cultural broker for his family through digital literacies. It explores the social and economic conditions and the roles that can be filled by a Latino adolescent when given adequate resources to learn and apply skills in technology. Eight months of observations in the home and family business along with formal and informal interviews served as the basis for field notes. Findings shed light on four ways in which the teen's digital literacy activities served the family by: a) contributing to his family's fiscal resources, b) brokering popular culture for his siblings, c) scaffolding content in the primary language, d) bridging generations and cultural knowledge. This study expands on emerging research of Latino adolescents' use of digital literacies. It also highlights how the funds of knowledge which immigrants bring from their homelands plays a key role in the educational, social, and economic achievement of their families.
\end{abstract}

